Portland State University

PDXScholar

$11-22-1978$

\title{
The Effect of Developmental Temperature on Morphology, Energy Metabolism, Growth Hormone and Thyroid Stimulating Hormone in Long-Evans Rats
}

Dana Elizabeth Quinn

Portland State University

Follow this and additional works at: https://pdxscholar.library.pdx.edu/open_access_etds

Part of the Animal Sciences Commons, and the Biology Commons Let us know how access to this document benefits you.

\section{Recommended Citation}

Quinn, Dana Elizabeth, "The Effect of Developmental Temperature on Morphology, Energy Metabolism, Growth Hormone and Thyroid Stimulating Hormone in Long-Evans Rats" (1978). Dissertations and Theses. Paper 2836.

https://doi.org/10.15760/etd.2830

This Thesis is brought to you for free and open access. It has been accepted for inclusion in Dissertations and Theses by an authorized administrator of PDXScholar. Please contact us if we can make this document more accessible: pdxscholar@pdx.edu. 
AN ABSTRACT OF THE THESIS OF Dana Elizabeth Quinn for the Master of Science in Biology presented November 22,1978.

Title: The Effect of Developmental Temperature On Morphology, Energy Metabolism, Growth Hormone and Thyroid Stimulating Hormone in Long-Evans Rats.

APPROVED BY MEMBERS OF THE THESIS COMMITTEE:
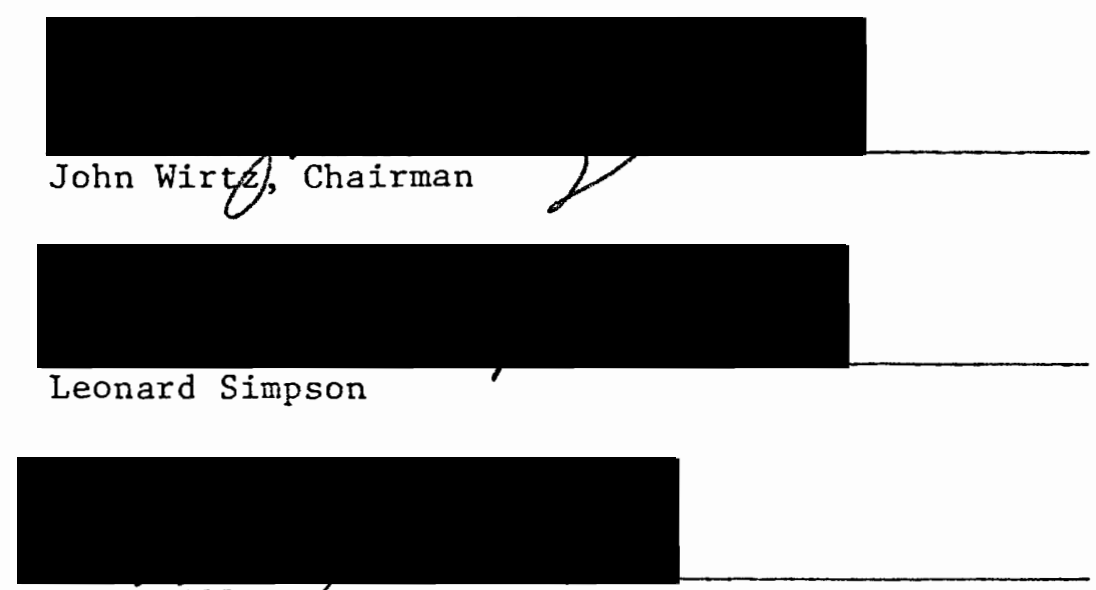

Stan Hillman?

Long-Evans rats were raised from birth to eight weeks of age at $5^{\circ} \mathrm{C}, 20^{\circ} \mathrm{C}$ and $30^{\circ} \mathrm{C}$. Blood was taken from animals two to eight weeks of age and assayed for growth hormone and thyroid stimulating hormone. The $30^{\circ} \mathrm{C}$ reared rats were found to have the iongest ear, tail and hind limbs, followed by the $20^{\circ} \mathrm{C}$ reared rats. The $5^{\circ} \mathrm{C}$ rats were found to have the shortest ear, tail and hind ilmb. The $30^{\circ} \mathrm{C}$ and $5^{\circ} \mathrm{C}$ reared rats were found to have similar masses at the termination of the experiment. The $20^{\circ} \mathrm{C}$ reared rats had the smallest mass. Differences in size between the three groups when compared on a weekly basis were not 
found to be related to weekly obtained serum levels of growth hormone and thyroid stimulating hormone. Food consumption was greatest for the $5^{\circ} \mathrm{C}$ reared rats followed by the $20^{\circ} \mathrm{C}$ reared rats. The $5^{\circ} \mathrm{C}$ reared rats were found to have the lowest routine metabolic rate in the $5^{\circ} \mathrm{C}$ chamber. The $20^{\circ} \mathrm{C}$ reared rats were found to have the lowest routine metabolic rate in both the $20^{\circ} \mathrm{C}$ and $30^{\circ} \mathrm{C}$ chamber.

When $30^{\circ} \mathrm{C}$ and $20^{\circ} \mathrm{C}$ reared rats were put in the $5^{\circ} \mathrm{C}$ chamber with the $5^{c} \mathrm{C}$ reared rats, they initially lost mass, however after three weeks in the $5^{\circ} \mathrm{C}$ chamber they began to gain mass. The $30^{\circ} \mathrm{C}$ reared rats gained mass at a greater rate than did the $20^{\circ} \mathrm{C}$ reared rats. The $5^{\circ} \mathrm{C}$ reared rats continued to gain mass throughout this period. While in the $5^{\circ} \mathrm{C}$ chamber the total food consumption of the $20^{\circ} \mathrm{C}$ reared rats was the greatest, whereas the $5^{\circ} \mathrm{C}$ and $30^{\circ} \mathrm{C}$ reared rats consumed similar amounts of food. 
THE EFFECT OF DEVELOPMENTAL TEMPERATURE ON MORPHOLOGY, ENERGY METABOLISM, GROWTH HORMONE AND THYROID

STIMULATING HORMONE IN

LONG-EVANS RATS

by..

DANA ELIZABETH QUINN

A thesis submitted in partial fulfillment of the requirements for the degree of

MASTER OF SCIENCE

in

BIOLOGY

Portland State University

1978 
TO THE OFFICE OF GRADUATE STUDIES AND RESEARCH:

The members of the Committee approve the thesis of Dana Elizabeth Quinn presented November 22, 1978.
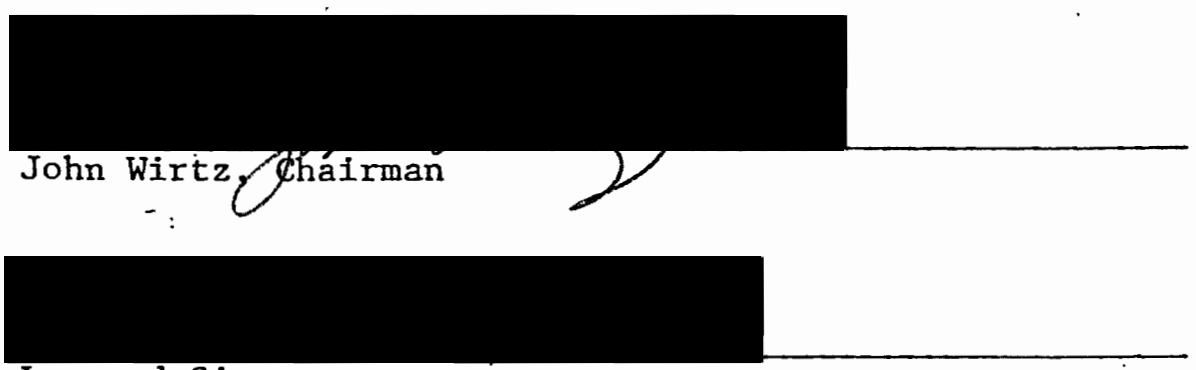

Leonard Simpson

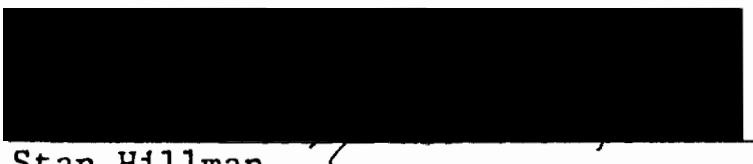

APPROVED :
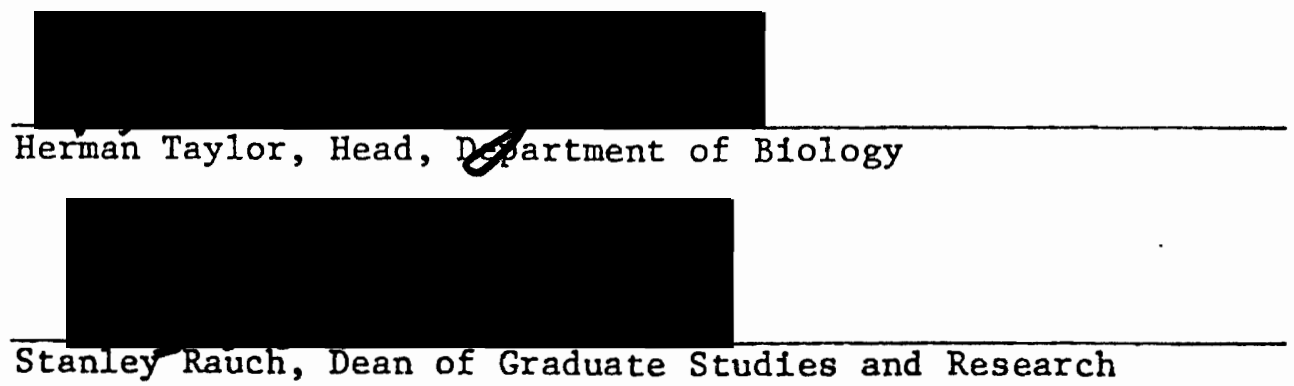


\section{ACKNOWLEDGMENTS}

I wish to thank the members of my committee, Dr. Stan Hillman, Dr. Leonard Simpson and Dr. John Wirtz for their help in the preparation of this thesis. I wish also to thank Dr. Richard Forbes of the Biology Department. I am also very grateful for the statistical guidance of Dr. Quentin Clarkson, Dr. Eugene Enneking, Mr. Wes Brenner and Mr. Paul Collins. I wish also to thank Dr. Rudi Nussbaum and Raymond Sommerfeldt of the Physics Department for their help in dealing with the isotope and gamma counter. I would like to espetcially thank Dr. Vaughn Crinchlow and Ms. Jesse Kroning of the University of Oregon Health Sciences Center, for their advice and for running the growth hormone assays for me. Finally I would like to thank Mr. Raymond Harry and Mr. James Campbell for helping me get it all together. 
IAABLE OH CONTEN'IS

PAGE

ACKNOWLEDGMENTS 111

LIST OF TABLES

$\mathbf{v}$

LIS'T OF FIGURES

CHAPTER

I INTRODUCTION • • . . . . . . . . . . • • • • • • •

I I REVIEW OF THE LITERATURE . . . . . . . . . . . . . . . 2

II MATERIALS AND METHODS . . . . . . . . . . . . . 12

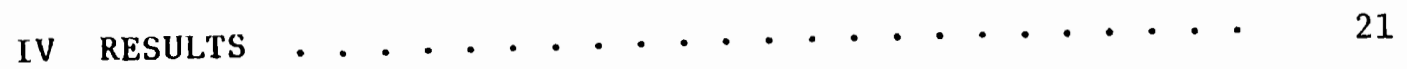

v DISCUSSION . . . . . . . . . . . . . . . . . . . 24

VI SUMMARY AND CONCLUSIONS • . . . . . . . . . . . . . . 29

31 


\section{LIST OF TABLES}

TABLE

PAGE

I Sumary of Morphologic Figures for Rats Raised at $5^{\circ} \mathrm{C}, 20^{\circ} \mathrm{C}$ and $30^{\circ} \mathrm{C}$ Expressed in Mean \pm Standard Diviation . . . . . . . . . . . . . 15

II Summary of the Significance of $F$ in the Morphologic Measurements from Table I . . . . . . . .

III Summary of Routine Metabolic Rates, $\left(10_{2} / g \cdot h\right)$, at $5^{\circ} \mathrm{C}, 20^{\circ} \mathrm{C}$ and $30^{\circ} \mathrm{C}$ of Rats Raised at $5^{\circ} \mathrm{C}, 20^{\circ} \mathrm{C}$ and $30^{\circ} \mathrm{C}$, Expressed in Mean \pm Standard Diviation .

IV Summary of the Significance of $F$ in the Routine Metabolic Rates, $\left(10_{2} / \mathrm{g} \cdot \mathrm{h}\right)$, Obtained at $5^{\circ} \mathrm{C}, 20^{\circ} \mathrm{C}$ and $30^{\circ} \mathrm{C}$, Using Rats Raised at $5^{\circ} \mathrm{C}, 20^{\circ} \mathrm{C}$ and $30^{\circ} \mathrm{C}$. . . . . . . . . . . . . .

V Sumary of Organ Weights per K1logram of Body Mass for Rats Raised at $5^{\circ} \mathrm{C}, 20^{\circ} \mathrm{C}$ and $30^{\circ} \mathrm{C}$, Expressed in Mean \pm Standard Diviation ...........

VI Summary of the Significance of $\cdot F$ in Organ Masses kilogram of Body Weight for Rats Raised at $5^{\circ} \mathrm{C}$, $20^{\circ} \mathrm{C}$ and $30^{\circ} \mathrm{C}$. . . . . . . . . . . .

VII Summary of the Mass (g) of Rats Ra1sed at $5^{\circ} \mathrm{C}, 20^{\circ} \mathrm{C}$ and $30^{\circ} \mathrm{C}$ at $5^{\circ} \mathrm{C}$ for 37 Days Expressed in Mean $t$ Standard Diviation ............... 


\section{LIST OF FIGURES}

PAGE

\section{FIGURE}

1. Thyrold Stimulating Hormone Levels Obtained Weekly

of Rats Raised at $5^{\circ} \mathrm{C}, 20^{\circ} \mathrm{C}$ and $30^{\circ} \mathrm{C}$, from

Two to Eight Weeks of Age . . . . . • • • •

2. Growth Hormone Levels Obtained Weekly of Rats Raised

at $5^{\circ} \mathrm{C}, 20^{\circ} \mathrm{C}$ and $30^{\circ} \mathrm{C}$, from Two to Eight Weeks 
CHAPTER I

INTRODUCTION

Morphologic measurements in endotherms have been shown to be related to temperature, $(1,4,5,15,34,38,39,63,69,71,86)$. Bergmann's rule states that a species of endotherm increases in size as the ambient temperature decreases. Allen's rule states that appendage size (ears, tail and limbs) decreases as ambient temperature decreases. Both of these rules indicate that endotherms will show minimized surface area in a cold environment and maximized surface area in a hot environment. Both rules are broad generalizations with many other factors involved in determining morphology and thermoregulatory capabilities of endotherms. These rules have been applied to the heat dissipatory and conservational mechanisms of the animal.

Growth hormone and thyroid hormone are of major importance with respect to mammalian growth, $(10,44,53,54,56,57,75,76,77)$. In addition to growth, thyroid hormone had been found to be important in the thermoregulatory capabilities of mammals, $(20,25,26,51,70)$. This has not been shown for growth hormone, though both hormones have been found to be greatly effected by ambient temperature, $(20,25,26,27,51,64,66,80)$.

The purpose of this study was an attempt to determine whether ambient temperatures govern levels of growth hormone and thyroid hormone which then govern resultant morphology. In addition, the effect of the resultant morphology on thermoregulatory capabilities of rats was studied. 


\section{CHAPTER II}

\section{REVEIW OF THE.LITERATURE}

Thermoregulation in rats is a composite of morphologic, physiological and behavioral factors. Important thermoregulatory behavior includes nest building, huddling and selection of appropriate thermal mifes. roenvironments, $(73,79)$. The temperature selected 1 s affected by the ambient temperature to which they have been previously acclimated, (79). Physiologic thermoregulation at low ambient temperatures may be accomplished in rodents through elevation of basal metabolic rate, ( 31 , $50,73,80)$, however other reserchers are not in agreement, $(12,36,87)$. At high ambient temperatures oxygen consumption may be depressed in an effort to thermoregulate, $(12,31,42,50,87)$, again there is dissagreement. Vascular phenomena associated with rats born and raised at different ambient temperatures also aids in the thermoregulatory capabilities of the animal, $(17,29,37,42,43,68,86)$. Mammals born and raised in a $5^{\circ} \mathrm{C}$ environment appear to demonstrate more vasoconstriction than mammals born and raised in a $30^{\circ} \mathrm{C}$ environment,(17). The peripheral tissues of the hot acclimated rodents are better supplied with blood hence greater growth is a possible result. The stunting of growth in a cold environment is more severe in the distal segments of the appendages. This also suggest a vascular phenomenon as the blood vessels are smaller In diameter toward the distal ends of the tail and limbs and therefore are more severely affected by lower environmental temperature, (17). 
Morphologic adaptations to temperature are generally concerned with body and appendage size as well as insulation. It is argued, however, whether body and appendage size are the result of temperature or adaptations to temperature. Bergmann in 1847 stated cold temperatures tend to delay sexual maturity thereby producing a longer growth period before reaching physical maturity. Allen said that in cold cl mates natural selection tends to favor those that have the advantage in surface area/volume ratio for the conservation of heat,(87). Metabolic rate can not be related to mass or a function of surface area alone but It is an important factor as the rate of heat transfer is proportional to surface area. The intensity of oxygen and nutrient flow is a function of the sum of the Internal surface which is porportional to body surface also, (29). Other factors of importance Influencing basal metabolic rate are central nervous system control, tissue cappillary density and genetic fixing, (29).

There are two very different effects of temperature on growth, as determined in the laboratory. When mice grown at $31-33^{\circ} \mathrm{C}$ are compared to mice raised at a cold temperature $\left(10^{\circ} \mathrm{C}\right)$ the mice reared in the lower temperature were heavier and longer than those reared in the higher temperature, $(1,33,63)$. In experments using different orders of mammals or different spectes of mice and rats, the cold reared animals, $\left(3-7^{\circ} \mathrm{C}\right)$, were lighter and smaller than animals kept at $21-30^{\circ} \mathrm{C},(5,17,38,42,54,83)$. It must be kept in mind however that these experimental procedures varied widely, for example some had a restricted food intake and some did not. The age of the animals subjected to the hot or cold environment and the age of the animal at the termination of the experiment also varied as did the length of time the animal remained in the rather severe environ- 
ment. All reports do agree, however, on the increased tail and appendage length in the hot environment, decreased length in the cold environment and intermediate length of the thermoneutral controls, $(1,5,17,33$, $38,63,83)$.

Generally speaking, a structure once formed usually has a biological significance which is independant of the way it was formed. Environmentally induced physiological changes are typically rapid reversible morphological changes which are strictly a function of growth and are irreversible once the structure has stopped growing,(30). The problem with body size is that it is most difficult to distinguish between its biological function and the magnitude of other functions which determine it. For example if it were that genetically small animals were better adapted to the heat than larger ones, one would not necessarily conclude that reduced growth at a high temperature is an adaptive response, (30).

Generally tails of animals in cold environments are shorter than those of animals living in warmer temperatures. This is belleved due to its role in the regulation of body temperature of the animal. A short tail with its smaller surface area may allow for heat conservation and a long tall with its relatively larger surface area may allow for heat dissipation, $(1,2,5,15,17,25,30,33,43,50,63,68,83)$. of course the circulatory changes previously mentioned will greatly influence this, i.e. a more vasoconstricted tall will promote heat conservation, whereas a more vasodilated tail will promote heat dissipation. Another factor not to be overlooked is the greater cutaneous circulation that accompantes a larger tall with its larger surface area.

Should the tail of the mouse or rat be amputated five weeks before exposure to the lethally high temperature, the survival time will be 
much lower than for rats and mice raised under the same conditions with their tails, $(30,33,34)$.

The length of the distal caudal vertebrae are more affected by temperature than that of the proximal caudal vertebrae which suggests a direct effect of temperature on tail growth. This is true of most murid and cricetid rodents that have been studied, $(1,15,30,33)$. Pigs show essentially the same results as the rodents, (86). The temperature induced differences in the tail are generally due to a change in the lengths of the individual vertebrae being most extreme in the distal segments. In some cases however the cold exposed animals had an actual decrease in the number of vertebrae, $(5,30,33,34)$.

The temperature of the tails of the rats studied were found to be nearly equal to the temperature of the environment 1.e. poik1lothermic, except when the animal is overheated or sitting on its tail, which they often do in a cold environment,(68). In rats not acclimatized to a hot environment vasodilation did occur, elevating their tail temperature. Rats not reared in a cold environment had a problem keeping their long tail warm and necrosis was often noted, (68).

In the fluctuating environment the time spent at the high temperature appears to be more influential in determining tail length than time spent at the low temperature, however the low temperature used was only $16^{\circ} \mathrm{C},(33)$.

If mice spend their pregnancy in a cold environment, $\left(10^{\circ} \mathrm{C}\right)$, and at weaning time half of their offspring are put in a hot environment, $\left(33^{\circ} \mathrm{C}\right)$, the offspring will grow long tails and the cold reared offspring will develop short tails. The general body length and weight of the mice put in the hot environment was retarded. A similar effect occurs when 
mice are born and reared in a hot environment and half of the offspring are put in the cold environment 1.e. the mice in the hot environment will develop long tails and the mice in the cold environment will develop short tails. Therefore the length of the tail appears to be a factor for increasing or decreasing the body surface area to facilitate heat loss or heat conservation.

Temperature studies on young pigs revealed that the lengths of the nasoocciput portion of the skull, lengths of the femur, tibia, first metatarsal, humerus, radius, ulna and metacarpal were invariably less in the cold exposed pigs, the heat reared were the longest and the controls intermediate, (86). The reason for this increase in length and and not so much width may be due to the proliferation of the chondrocytes in the epiphyseal plate being more affected than the proliferation of the osteoblasts under the periostium. Since cartilage itself has no blood vessels and relies on nutrients that diffuse through the matrix from the outside, such a general decrease in blood flow in response to the cold will greatly reduce this supply and hence the proliferative activity of the chondrocytes. The more highly vascularized deeper periosteum would be less affected by a change of vasomotor tone in a cold environment, $(15,52)$.

In male laboratory albino rats the growth curves of the cold rats gradually diverged from those of the controls in the first few weeks. During the later weeks of the experiment the two curves ascended more or less in parallel. In the control rats the rates of gain in body length and tail length were greatest at the start and then followed a straight Iine decline during the first few weeks of the experiment,(15). 
The growth rate of the body length in the cold rats averaged about $3 / 4$ the amount of the controls during the first week in the cold and this rate was maintained for three weeks until its curve met the declining growth curve of the controls and then the two temperature groups grew at the same rate until the termination of the experiment, (15). From this it appears that growth retardation by the cold is the most severe during the first few weeks of exposure to the cold, (the rats were a1ready weaned upon exposure to the cold). The period of growth retardation by the cold ends at about six weeks of age in mice,(2). Suceptability of a mouse's growth to cold begins before weaning, (69).

Genera11y speaking there appears to be three growth cycles in endotherms; first there is a rapid growth rate which tapers off up to maturity and this is followed by a much slower increase and actually decreases during senility, (87).

Several investigators have suggested that growth of rats and mice should be greatest under optimum conditions, that is, the most favorable temperature ranges and it should be retarded under less favorable conditions such as too hot or too cold,(15). This has not been the case, however. The differences in growth are partly related to the metabolic effort that the young mouse or rat must make to compensate for the heat loss from its relatively large surface area when subjected to the cold (however if the animal were born and raised in the cold perhaps the surface area would be comparatively smaller).

Other factors affecting growth rates include seasonal effects,(17), number of rats per cage, $(17,36)$, and genetic factors, (33). Weight gain and photoperiod appear not to be related, $(17,36)$. 
regulation of metabolic rate. Elevated thyroidal function results in increased oxygen consumption and depressed thyroidal function results in decreased oxygen consumption.

Thyroid hormones are also important in the development of the nervous system, reflex responses, mental activities and reproductive system functions. Not all tissues exhibiting strong responses to thyroid hormones show associated increases in oxygen uptake.

When rats are exposed to the cold there is an increase in the basal metabolic rate which is due in part to augmented activity of the thyoid gland, $(18,19,26,39,48,51,70,80)$. The maintenance of the higher metabolic rate also requires adrenal gland secretions, $(13,18,45)$. The elevation of basal metabolic rate in cold temperatures can be abolished by thyroidectomy, (80). The accelerated thyrold hormone release is temporary reaching its maximum 26 days after exposure to the cold and being virtually absent 40 days after exposure to the $\operatorname{cold}\left(0-2{ }^{\circ} \mathrm{C}\right),(5)$.

Thyroidal cold responses involve the pituitary stalk. Without the pituitary stalk there is only enough thyroid stimulating hormone produced to keep the thyroid activities normal under normal conditions, however, it will not exhibit the cold response, i.e. elevated thyroldal function. The hypothalamus receives its thermal information from the central nervous system and increases the thyroid stimulating hormone through impulses transmitted through the stalk. The basic secretory rinythm, must be independent of the pituitary stalk under normal conditions and under humoral influences. The hypothalamus and pituitary stalk must participate in regulation of the anterior pituitary secretions in specific adjustments to certain environmental situations, $(5,14,19,20,21,48)$. 
Experiments have shown that thyroid hormone production is counterbalanced by peripheral degradation of extrathyroidal hormone which increases as ambient temperature decreases and vice versa, $(7,8,9,16,24,25$, $26,70)$. Thus the thyroid gland behaves as though its secretion were essential to the internal environment through a compensatory homeostatic increase in the production of thyroid stimulating hormone when thyroid utilization increases, $(16,70)$. Since the pituitary production of thyroid stimulating hormone stimulates the thyroid's production and secretion of thyroid hormone and since thyroid stimulating hormone is not maintained at nearly normal levels, it should be a more accurate measure of thyroid activity than a measure of thyroid hormone would be.

The initial elevation of plasma levels of thyroid hormone in response to lowered temperature may be in part due to a change in the distribution of the hormone as well as increased secretion, $(8,24)$. Thyroid hormone may be released from sites in the liver for example. The rate of thyroid loss to the feces increases after exposure to the cold which may account for the elevated secretion of thyroid hormone. However, this is also in part dependent on elevated food consumption and increased passage of material along the intestine. The extent of which the rapid passage might impair thyroid hormone reabsorption is not clear, $(7,8,11,24$, $25,39)$.

Growth hormone levels are affected by plasma glucose levels, stress, bacterial pyrogens, neurotransmitters, hypothalmic stimulatory and inhibItory hormones and short feedback control. Growth hormone also appears to be affected by temperature, however little work has been done with rats in this area. Ultimate body size which is greatly affected by growth hormone may play a role in thermoregulation, for example a larger surface 
area to mass ratio may allow for increased heat dissipation. If temperature does indeed have an effect on growth hormone, it should be apparent in ultimate body size.

In rats exposed to cold temperatures there is a marked depletion of pituitary growth hormone, within one hour of exposure, (25). These depletions are interpreted to mean that a release of the hormone has occured resulting in elevated plasma growth hormone. This depletion returns to normal or slightly elevated values within two hours after the acute depletion, (25). This does not appear to be due to stress as in the rat a stressfull situation will cause a decrease in the plasma growth hormone levels unlike most other mammals, (24).

Growth hormone levels do not increase in cold exposed humans, but upon rewarming they greatly increase, $(13,18,19,20)$. Shivering may be related to human growth hormone release but data is lacking; (19). In heat exposed humans growth hormone levels will gradually in crease, (13). A sharp increase will occur if excercise is performed. Since there are not significant increases in people given prior administration of glucose, it may be that the increased human growth hormone response is induced by diminished energy substrate, (20). Obese people invariably had a smaller human growth hormone response, (20). It should be concluded that excercise is an important variable and that although the size of the animal is affected by growth hormone, growth hormone apparently is also affected by the size of the animal.

Both thyroid hormone and growth hormone act on a large number of cell types. Thyroid hormones synergize with growth hormone in supporting 
skeletal growth, although thyroid hormone unlike growth hormone promotes bone maturation, $(9,10,23,54,58,76,77)$. Thyroid hormones also act on the hypothalamus and pituitary gland to increase growth hormone secretion. Reproductive and nervous system maturation are other important functions of thyroid hormones in animal development. Both growth and thyroid hormones play an important role in the overall weight of the anima1, $(58,76)$.

Thyroid hormone and growth hormone administered to both normal and hypophysectomized animals causes a greater increase in weight than either of the two alone. Growth hormone exhibits the plateauing effect in that the initial dosage becomes ineffective after approximately 100 days for Long-Evans rats, $(21,55,57)$. Thyroid hormone, unlike growth hormone, does not exhibit the plateaning effect,(57).

When a normal Long-Evans rat is given growth hormone injections, all organs appear to increase in mass to the proportion as skeletal mass,(53). The fibers of the skeletal and cardiac musculature were hypertrophied as was the connective tissue fiber,(55). 
CHAPTER III.

MATERIALS AND METHODS

Three sets of four male rats of the Long-Evans strain were used. One set was put into a $5^{\circ} \mathrm{C}$ environmental chamber and the second set was put into a $30^{\circ} \mathrm{C}$ environmental chamber. The third set (the controls) were kept at room temperature $\left(20^{\circ} \mathrm{C}\right)$ in the animal room. The mothers of these rats gave birth not less than 30 days after they had been put into the environmental chambers, indicating mating and pregnancy occured in the environmental chambers. Photoperiod was set at 14 hours to coincide with that of the animal room. Bedding in the form of newspaper strips was supplied for the purpose of nest formation. An excess of food and water were supplied. The offspring (approximately 10 per female) were not in any way handlied until weaning.

At weaning all males were taken from each of the three groups. These males were put into individual wire bottom cages. without bedding to prevent nest bullding and huddling. Four of the males from each group were weighed once weekly and amounts of Purina Lab Chow consumed was recorded. Body, tall, hind foot and ear lengths were also recorded on these four males. Blood was obtained once weekly from the four males via tail vein puncture. The blood was then centrifuged in test tubes coated with EDTA. The serum was collected and stored at $-40^{\circ} \mathrm{C}$, to be assayed at a later time for growth hormone and thyroid stimulating hormone. 
After weaning the mothers were given a seven day rest period, after which the males (same as initially used) were reintroduced into the cage. After the second parturition of the three mothers, four male offspring from each of the three groups were killed in order to obtain a two week sample of blood. Weights and measurements of the body length, tail, hind limb and ear were also obtained. This proceedure was repeated with offspring taken at the three week period.

Total length. was taken as the length from the tip of the snout to the tip of the tail. Body length was considered as the total length minus the tail length. The tail length was considered as the base of the tail (end of the well haired portion of the body) to the tip of the tail. Lengths of the hind limbs began at the heel and ran to the tip of the longest claw. The ear was measured from notch to the apex.

At the termination of the experiment routine metabolic rates were taken on the four males from each of the three groups. The routine metabolic rates were studied at $5^{\circ} \mathrm{C}, 20^{\circ} \mathrm{C}$ and $30^{\circ} \mathrm{C}$ for all three groups in random order. The rats resided in gallon jars used for the routine metabolic rate measurements 24 hours prior to measurement. Samples of air from inside the jar were taken at the beginning and end of a five -. minute period and run through the Beckman Oxygen Analyzer model OM-14. This was done five times for each rat. The highest and lowest samples. were omitted from the calculations.

Wet weights of the liver, heart and kidneys were recorded at nine weèks of age.

The serum was assayed via radioimmunoassay for thyroid stimulating hormone and growth hormone.

The remaining male rats from each of the environmental chambers 
were all put in the cold $\left(5^{\circ} \mathrm{C}\right)$ chamber. At this point the cold reared rats were nine weeks of age, the heat reared were 10 weeks of age and the control reared were 11 weeks of age. Amounts of food consumed were recorded. The mass of the rats were recorded at three, five and six weeks after exposure to the cold. 


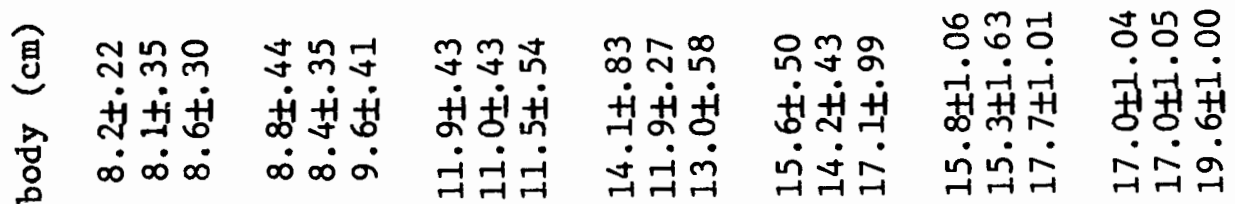

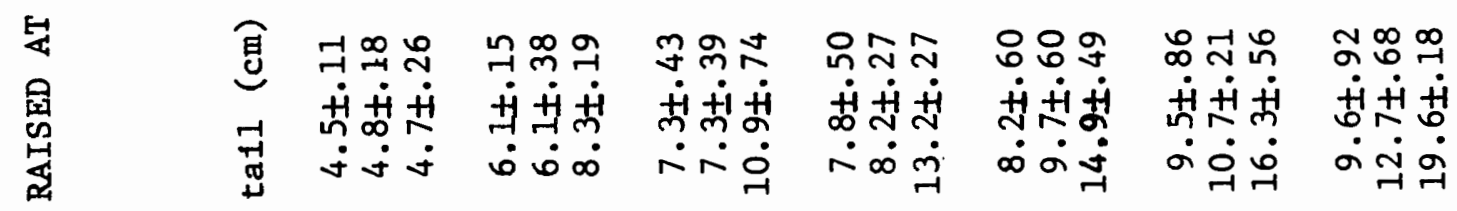

兒台

요

o

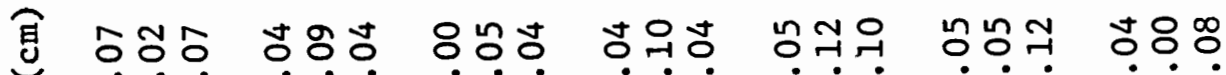

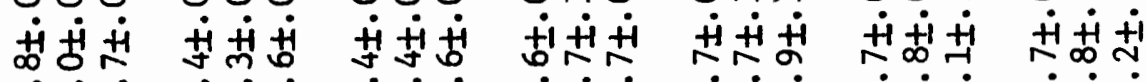

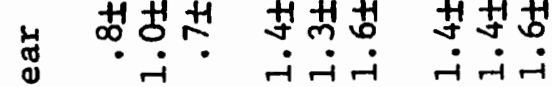

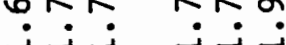
$\dot{i} \dot{i} \dot{i} \dot{i} \dot{i} \dot{N}$

ऽ。

ปัન ๓ Hे $\dot{\text { Hे }}$ $\dot{H} \dot{H} \dot{H}$ $\dot{H} \dot{H} \dot{H}$ ثै +j Hे山्में 豆 $\dot{i}-\dot{-i}$ iें $\dot{m} \dot{\sim}$ लिं $\dot{m}$ $\dot{m} \dot{\dot{\sigma}} \dot{m} \dot{m} \dot{j}$
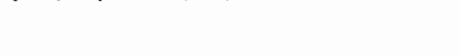

\section{(0)}

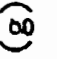

ํํㅇ

농ㅇㅇㅇㅇㅢ

ำก

ป

ํํㅇ응ㅇㅇㅇ

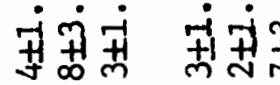
ஸें் $\dot{\infty} \dot{0} \dot{0}$ $\dot{\forall} \dot{0}$ 至 함 $\dot{\infty} \dot{\sim} \dot{q}$ ஸि mं ํㅏㅁ

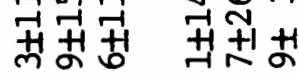

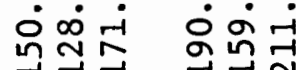

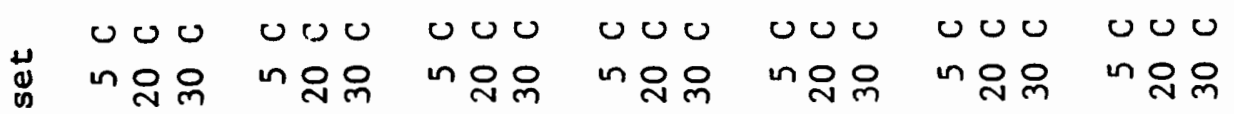

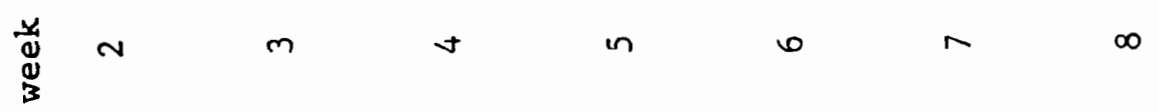


TABLE II

SUMMARY OF THE SIGNIFICANCE OF F IN THE MORPHOLOGICAL MEASUREMENTS

FROM TABLE I

Control VS Cold

$\begin{array}{cl}\text { week } & \text { mass } \\ 2 & 1.000 \\ 3 & .014 \\ 4 & .000 \\ 5 & .001 \\ 6 & .137 \\ 7 & .104 \\ 8 & .125\end{array}$

hind foot

ear
.011
.067
.134
.094
.537
.050
.002

tail

body

.705

.154

.630

.168

.020

.024

.670

.488

1.000

.291

.886

.043

.267

.005

.016

.011

.746

.060

.642

.003

.995

Control VS Hot

$\begin{array}{cc}\text { week } & \text { mass } \\ 2 & .458 \\ 3 & .010 \\ 4 & .008 \\ 5 & .001 \\ 6 & .005 \\ 7 & .008 \\ 8 & .015\end{array}$

hind foot

.670

.000

.001

.000

.001

.001

.001

$$
\text { ear }
$$

.001

.001

.000

.705

.071

.004

.000 tail

.895

.000

.000

.000

.000

.000

.000 body

.102

.007

.253

.025

.029

.048

.005

Hot VS Cold

$\begin{array}{cccccc}\text { week } & \text { mass } & \text { hind foot } & \text { ear } & \text { tail } & \text { body } \\ 2 & .458 & .056 & .134 & .323 & .114 \\ 3 & .000 & .000 & .000 & .000 & .046 \\ 4 & .000 & .045 & .000 & .000 & .353 \\ 5 & .773 & .000 & .005 & .000 & .116 \\ 6 & .039 & .000 & .008 & .000 & .193 \\ 7 & .068 & .001 & .001 & .000 & .033 \\ 8 & .048 & .000 & .000 & .000 & .005\end{array}$


TABLE III

SUMMARY OF ROUTINE METABOLIC RATES $\left(10_{2} / \mathrm{g} \cdot \mathrm{h}\right)$ AT $5^{\circ} \mathrm{C}, 20^{\circ} \mathrm{C}$ AND $30^{\circ} \mathrm{C}$ OF RATS RAISED AT $5^{\circ} \mathrm{C}, 20^{\circ} \mathrm{C}$ AND $30^{\circ} \mathrm{C}$ EXPRESSED

IN MEAN \pm STANDARD DIVIATION

Temp. Rat Reared Conditions Under Which Metabolic Rates Were Taken

$$
\begin{array}{rccc} 
& 5^{\circ} \mathrm{C} & 20^{\circ} \mathrm{C} & 30^{\circ} \mathrm{C} \\
5^{\circ} \mathrm{C} & .00249 \pm .00003 & .00210 \pm .00009 & .00173 \pm .00008 \\
20^{\circ} \mathrm{C} & .00289 \pm .00045 & .00156 \pm .00022 & .00142 \pm .00016 \\
30^{\circ} \mathrm{C} & .00335 \pm .00017 & .00276 \pm .00019 & .00206 \pm .00005
\end{array}
$$

TABLE IV

SUMMARY OF THE SIGNIFICANCE OF F IN THE ROUTINE METABOLIC RATES $\left(10_{2} / \mathrm{g} \cdot \mathrm{h}\right)$ OBTAINED AT $5^{\circ} \mathrm{C}, 20^{\circ} \mathrm{C}$ and $30^{\circ} \mathrm{C}$ USING RATS RAISED AT $5 \mathrm{C}$, $20^{\circ} \mathrm{C}$ AND $30^{\circ} \mathrm{C}$

$\begin{array}{lccc}\text { Groups Compared } & \text { Conditions Under Which Metabolic Rates } & \text { Were Taken } \\ & 5^{\circ} \mathrm{C} & 20^{\circ} \mathrm{C} & 30^{\circ} \mathrm{C} \\ 5^{\circ} \mathrm{C} \text { VS } 20^{\circ} \mathrm{C} \text { reared } & .331 & .041 & .082 \\ 20^{\circ} \mathrm{C} \text { VS } 30^{\circ} \mathrm{C} \text { reared } & .287 & .005 & .007 \\ 30^{\circ} \mathrm{C} \text { VS } 5^{\circ} \mathrm{C} \text { reared } & .002 & .011 & .014\end{array}$

\section{TABLE V}

SUMMARY OF ORGAN MASS (\% BODY MASS) FOR RATS RAISED

AT $5^{\circ} \mathrm{C}, 20^{\circ} \mathrm{C}$ and $30^{\circ} \mathrm{C}$, EXPRESSED IN

MEAN \pm STANDARD DIVIATION

Temp. Rat Reared

Rat Reared
$5^{\circ} \mathrm{C}$
$20^{\circ} \mathrm{C}$
$30^{\circ} \mathrm{C}$

$\begin{array}{cc}\text { heart } & \text { kidney } \\ .0045 \pm .0002 & .0077 \pm .0003 \\ .0035 \pm .0007 & .0080 \pm .0010 \\ .0036 \pm .0007 & .0063 \pm .0005\end{array}$

1 iver

$.0450 \pm .0017$

$.0348 \pm .0046$

$.0369 \pm .0042$

TABLE VI

SUMMARY OF THE SIGNIFICANCE OF F IN ORGAN MASS

(\% BODY MASS) FOR RATS RAISED AT

$$
5^{\circ} \mathrm{C}, 20^{\circ} \mathrm{C} \text { AND } 30^{\circ} \mathrm{C}
$$

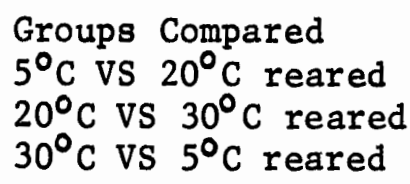

heart

.059

.847

.084

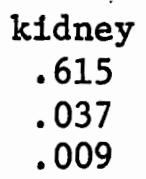

liver

.011

.661

.088 
TABLE VII

SUMMARY OF THE MASS (g) OF RATS RAISED AT $5^{\circ} \mathrm{C}, 20^{\circ} \mathrm{C}$ AND $30^{\circ} \mathrm{C}$ AT $5^{\circ} \mathrm{C}$ FOR 37 DAYS, EXPRESSED IN

MEAN \pm STANDARD

DIVIATION

Weeks at $5^{\circ} \mathrm{C}$

0

3

4

5
Temp. Reared $5^{\circ} \mathrm{C}$

$237.0 \pm 2.3$

$268.3 \pm 6.5$

$285.0 \pm 19.2$

$295.3 \pm 15.4$ $20^{\circ} \mathrm{C}$

$203.6 \pm 6.4$

$185.6 \pm 3.5$

$181.3 \pm 5.3$

$207.8 \pm 3.8$ $30^{\circ} \mathrm{C}$

$291.6 \pm 5.5$

$255.7 \pm 27.6$

$263.0 \pm 33.7$

$276.0 \pm 38.2$ 


\section{FIGURE 1}

THYROID STIMULATING HORMONE LEVELS OBTAINED WEEKLY

OF RATS RAISED AT $5^{\circ} \mathrm{C}, 20^{\circ} \mathrm{C}$ AND $30^{\circ} \mathrm{C}$, FROM

TWO TO EIGHT WEEKS OF AGE

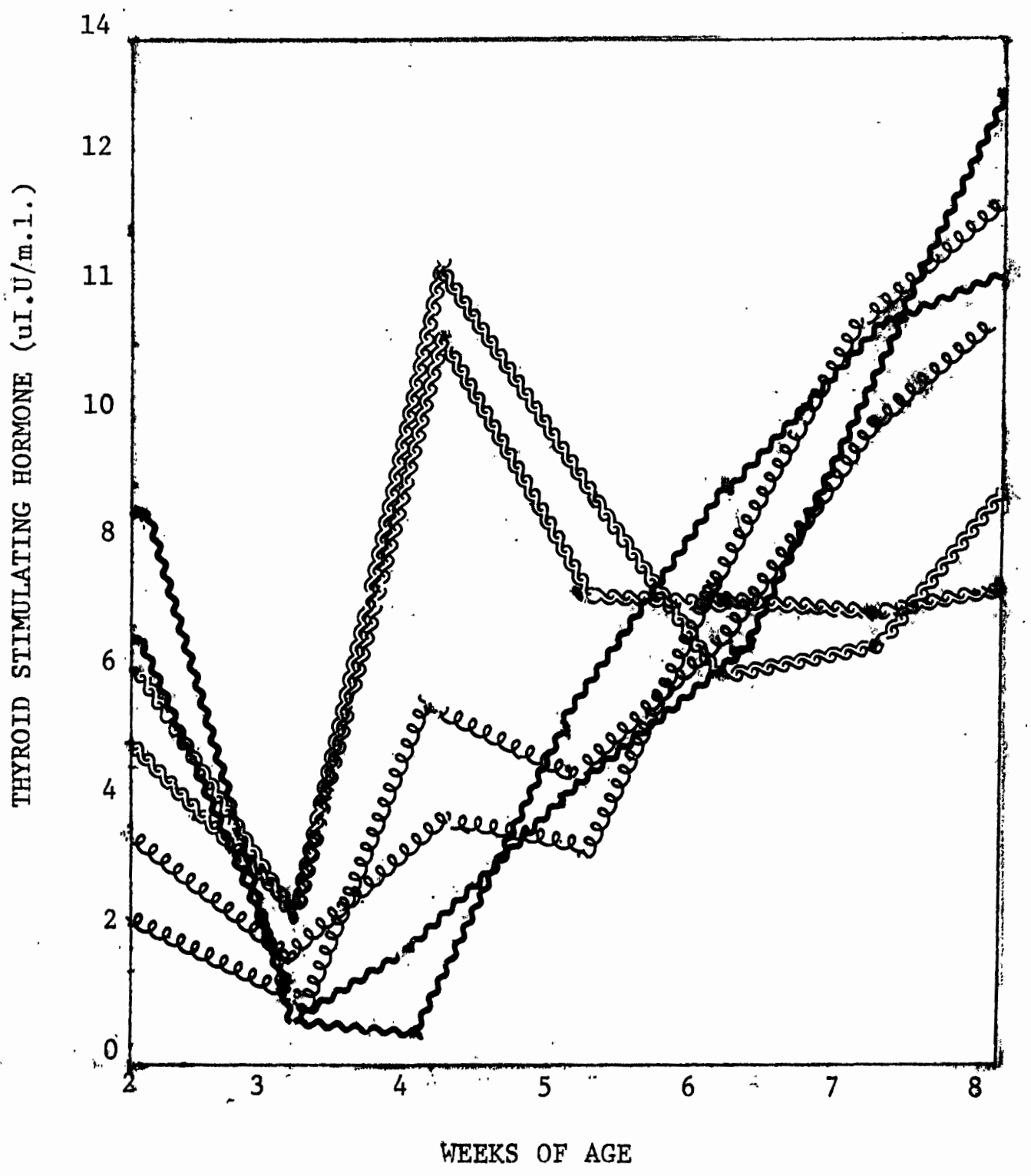

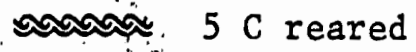

20 C reared

eceever. $30 \mathrm{C}$ reared 
FIGURE 2

GROWTH HORMONE LEVELS OBTAINED WEEKLY OF RATS RAISED AT $5^{\circ} \mathrm{C}, 20^{\circ} \mathrm{C}$ AND $30^{\circ} \mathrm{C}$, FROM TWO

TO EIGHT WEEKS OF AGE
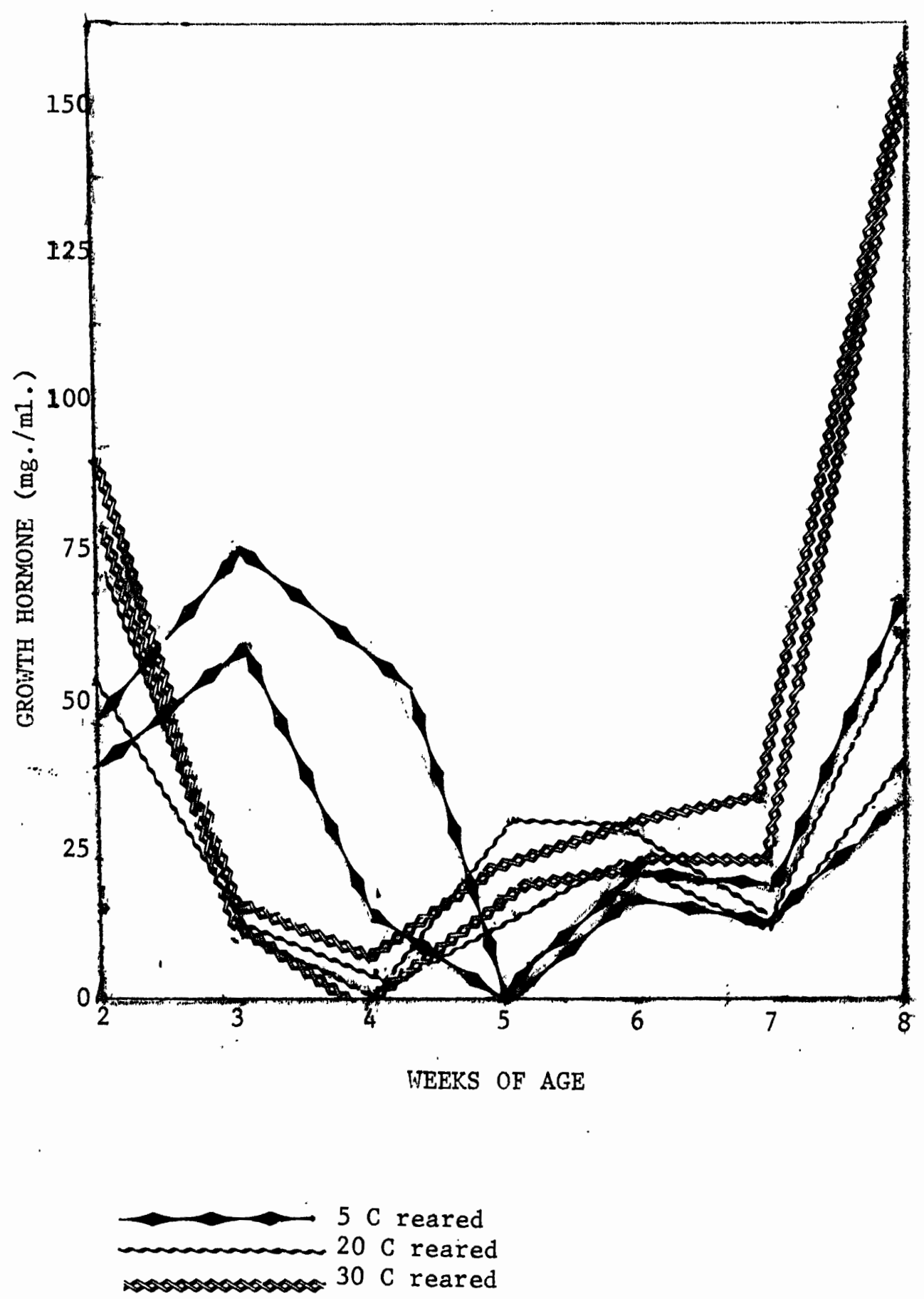


\section{CHAP'TER IV}

\section{RESULTS}

Tables I and II give the morphologic figures and their significance obtained from two to eight weeks of age. The $5^{\circ} \mathrm{C}$ and $30^{\circ} \mathrm{C}$ reared rats showed the greatest difference in hind foot, ear and tail size, the $30^{\circ} \mathrm{C}$ being the largest from the third week on. The greatest difference in hind foot, tall and ear length occured during the eighth week $(P<$ $.000)$. A comparison of the $20^{\circ} \mathrm{C}$ and $30^{\circ} \mathrm{C}$ reared rats hind foot and ear was not nearly as striking however the tail lengths were significantly different $(P<.000)$ from three to eight weeks of age. The differences In lengths of the hind foot, ear and tall in the $20^{\circ} \mathrm{C}$ and $5^{\circ} \mathrm{C}$ reared rats were generally nonsignificant. The ear and tail lengths at eight weeks of age were however, significantly different $(\mathrm{P}<.005)$. The mass and body length were only consistently different $(\mathrm{P}<.050)$ in the $20^{\circ} \mathrm{C}$ and $30^{\circ} \mathrm{C}$ reared rats.

The routine metabolic rates and their significance are given in tables III and IV. The $5^{\circ} \mathrm{C}$ reared rats followed closely by the $20^{\circ} \mathrm{C}$ reared rats had the lowest routine metabolic rate in the $5^{\circ} \mathrm{C}$ chamber. The $30^{\circ} \mathrm{C}$ reared rats had higher routine metabolic rates $(\mathrm{P}<.050)$ than the $5^{\circ} \mathrm{C}$ and $20^{\circ} \mathrm{C}$ reared rats had in both the $20^{\circ} \mathrm{C}$ and $30^{\circ} \mathrm{C}$ chambers.

Tables V and VI give the organ weights and their significance obtained from eight week old male rats reared at $5^{\circ} \mathrm{C}, 20^{\circ} \mathrm{C}$ and $30^{\circ} \mathrm{C}$. The differences in heart, liver and kidney sizes were generally not striking. 
The liver of the $5^{\circ} \mathrm{C}$ reared rats compared to the $20^{\circ} \mathrm{C}$ reared rats differed significantly $(\mathrm{P}<.011)$. The kidneys of the $30^{\circ} \mathrm{C}$ reared rats were significantly lighter $(\mathrm{P}<.040)$ than either the $5^{\circ} \mathrm{C}$ or $20^{\circ} \mathrm{C}$ reared rats.

The amounts of food consumed from four to eight weeks of age were greatest for the rats in the $5^{\circ} \mathrm{C}$ chamber $(828.7 \mathrm{~g} \pm 69.5)$ followed by the rats in the $20^{\circ} \mathrm{C}$ chamber $(642.9 \pm 71.7)$. The least amount of food was consumed by the rats reared in the $30^{\circ} \mathrm{C}$ chamber, $(504.8 \mathrm{gt} \pm 37.6)$. of the five $30^{\circ} \mathrm{C}$ reared rats that were put into the $5^{\circ} \mathrm{C}$ chamber, three died, however death was not immediate. One of the $30^{\circ} \mathrm{C}$ reared rats died after three days and the other after 13 days in the $5^{\circ} \mathrm{C}$ chamber. Both the $30^{\circ} \mathrm{C}$ and $20^{\circ} \mathrm{C}$ reared rats had a reduction in mass during the first three weeks in the $5^{\circ} \mathrm{C}$ chamber. The $30^{\circ} \mathrm{C}$ reared rats were all gaining mass after three weeks in the $5^{\circ} \mathrm{C}$ chamber (see table VII). The food consumption by the $20^{\circ} \mathrm{C}$ reared rats in the $5^{\circ} \mathrm{C}$ chamber was the greatest of the three groups. This amounted to $1332.5 \mathrm{~g} \pm 40.7 \mathrm{com}-$ pared to $1095.6 \mathrm{~g} \pm 4.4$ consumed by the $30^{\circ} \mathrm{C}$ reared and $1176 \mathrm{~g} \pm 55.6$. consumed by the $5^{\circ} \mathrm{C}$ reared rats.

Bleeding and necrosis of the tails of the $30^{\circ} \mathrm{C}$ reared rats occured after three to four weeks in the $5^{\circ} \mathrm{C}$ chamber. The tips of the tails of the $20^{\circ} \mathrm{C}$ reared rats appeared flushed, however they never bled or necrosed. The tails of the $5^{\circ} \mathrm{C}$ reared rats in the $5^{\circ} \mathrm{C}$ chamber were vasoconstricted throughout the entire experiment.

Serum thyroid stimulating hormone and growth hormone levels obtained weekly from two to eight weeks of age from the three temperature groups are given in figures 1 and 2. The results indicate both hormones are affected by temperature, however it can not be determined from the data presented exactly how they are affected. Increases in mass and 
lengths of the hind 1imb, ear, tail and body generally did not correlate with changes in the concentration of growth hormone or thyroid stimulating hormone. 


\section{CHAPTER V}

\section{DISCUSSION}

The results indicate that morphologically Allen's rule holds, however, Bergmanns's rule does not hold during the first eight weeks of 1ife. The morphologic changes that occur when in the cold do not appear to be a thermoregulatory advantage as the heat reared rats, with their longer extremities, gained weight when put in the cold chamber at a rate similiar to the cold reared rats. However during the first three weeks of cold exposure the heat reared rats, as well as the control reared rats, lost mass. This may represent a period of physiologic adjustment. Were the experiment to terminate at this point it would appear that the morphologic adjustments were of adaptative importance. In addition to gaining weight at a similar rate as the cold reared rats, the heat reared rats consumed similar amounts of food as did the cold reared rats over the entire five week period in the $5^{\circ} \mathrm{C}$ chamber. It can not be concluded from this experiment whether or not there is an adaptive advantage to having a long tail, ear and hind $11 \mathrm{mb}$ in a hot environment as the cold reared rats were not put in the $30^{\circ} \mathrm{C}$ chamber with the heat reared rats.

The smaller mass of the control reared rats may be due to a lack of stressful conditions to stimulate growth. When the controls were put in the $5^{\circ} \mathrm{C}$ chamber they ate more than the heat and cold reared and had more difficulty in adjusting to the cold environment. Perhaps a constant 
exposure to thermostress enhances biochemical, neural and cardiovascular systems in a manner similar to training effects.

The shortness of extremities in the cold reared rats may be due to a lack of advantageous conditions to stimulate their growth. Since body temperature is kept relatively constant, the mass and body length of the rat would be less affected than the more exposed tail, ear and hind limb. This would be reversed in a hot environment.

Bleeding and necrosis did occur after the heat reared rats had been in the $5^{\circ} \mathrm{C}$ chamber for three to four weeks. This resulted in a loss of up to eight centimeters of tail. It appears these rats were vasodilating to keep their long tails warm, this would certainly have ramifications in heat loss though the magnitude of this is unknown. The point at which they began to gain weight did coincide with the onset of necrosis, however this may be mere coincidence. The control reared rats when put in the $5^{\circ} \mathrm{C}$ chamber did not show bleeding and necrosis of their tails. Their tails were flushed however, throughout the five week period in the cold chamber indicating vasodilation did occur.

It is interesting to note that when 30 week old rats of the same litter were put into the environmental chambers, the rats in the $5^{\circ} \mathrm{C}$ chamber gained weight and eventually grew much larger than the rats in the $30^{\circ} \mathrm{C}$ chamber. The amount of food consumed by the cold rats was also much greater.

Amounts of food consumed between four to eight weeks of life were greatest for the cold reared rats indicating a greater energy requirement. The heat reared rats ate less but attained a mass that was 
significantly greater, at the .05 level of significance, than the control and cold reared. rats. This indicates a smaller expenditure of energy was required to maintain body temperature. The activities of the animals should of course be taken into consideration, however they were not observed in this experiment.

The routine metabolic rates recorded were not a true resting conditions as the jar lids had to be removed between each routine metabolic measurement causing some disturbance to the rats. All measurements were obtained under the same conditions. The routine metabolic rates of the heat reared rats in the $5^{\circ} \mathrm{C}$ chamber were quite high compared to the cold reared rats, indlcating the cold reared rats were better acclimated to the $5^{\circ} \mathrm{C}$ temperature. The heat reared rats had the highest routine metabolic rates under control conditions showing they were also least efficient under control conditions compared to the control and cold reared. The heat reared rats did not have the lowest routine metabolic rates of the three groups in the $30^{\circ} \mathrm{C}$ chamber. This could possible mean that they were physiologically equipped to deal with the $30^{\circ} \mathrm{C}$ temperature and could carry out normal functions, whereas the cold and control reared could not. It is interesting to note that the morphologic measurements and routine metabolic measurements of the control and cold reared were generally quite similar compared to the control and the heat reared or the cold and the heat reared.

It should be noted that the cold reared rats could not be put into separate cages after 21 days of age as the other two groups were. When this was first tried all the rats died, presumably due to an inability to thermoregulate. Therefore the cold rats were not put into individual cages until they were 25 days old. The mother was, however, removed at 
21 days of age.

Serum thyroid stimulating hormone levels were not found to be related to the mass of the rat when rats of the same age were compared. There did appear to be a relation to temperature of the chamber in which the rat was ralsed as by the eighth week of life the control and heat reared rats had attained much higher levels of thyroid stimulating hormone than did the cold reared rats. This difference was very small for the heat reared rats, however blood was only taken once weekly starting at two weeks of age. The rather abrupt rise in serum thyroid stimulating hormone that occured in the four week old cold reared rats corresponded to the removal of the mother from the nest resulting in a more thorough exposure to the $5^{\circ} \mathrm{C}$ environment in addition to a certain amount of stress from the mothers absence (this is shortly after the rats had aquired the ability to thermoregulate). The heat reared rats would cert tainly have less metabolic adjustments to make compared to the cold reared rats once the mother is removed, although the placement of these rats into individual cages should cause some stress. This may be why the abrupt increase of thyroid stimulating hormcne during the fourth week of the heat reared rats was considerably smaller in the cold reared rats. The control reared rats did not show this abrupt increase at four weeks of age, however it must be remembered that blood was only taken once a week and there may have been a similar increase during the interval of the third and fourth weeks or fourth and fifth weeks of 1 ife. The lower levels of serum thyroid stimulating hormone seen in the cold reared rats from the fifth week through the eighth week of IIfe compared to the fourth week may represent metabolic adjustments made by the rats to the cold environment. Of course the different sensitivities of the 
rats to thyroid stimulating hormone should be taken into consideration. Serum growth hormone levels were only found to correlate with size at eight weeks of age, the heat reared rats having the highest levels. Prior to this no correlation was seen. The serum growth hormone levels of the hot, cold and control reared groups were different when compared on a week by week basis, indicating a temperature effect, although it is difficult to determine the significance of this difference. Of course the different sensitivities the rats may have to growth hormone, also the pulses of growth hormone should be taken into consideration. It should also be remembered that blood was only taken once week1y. 
CHAPTER VI

SUMMARY AND CONCLUSIONS

Long-Evans rats from the same litter were placed into one of two environmental chambers, one male and one female per cage. One environmental chamber was set at $5^{\circ} \mathrm{C}$ and the other at $30^{\circ} \mathrm{C}$. A third set was kept under control conditions i.e. $20^{\circ} \mathrm{C}$. Measurements of the hind foot, ear, tail and mass were taken from four of the male offspring from each group, as was blood to be assayed for thyroid stimulating hormone and growth hormone. This was done from two to eight weeks of age. The heat reared males were found to have a significantly longer tall, ears and hind foot when compared to the control reared and least pronounced when the cold reared were compared to the control reared. The control reared rats were found to have a significantly less.mass than either the heat reared or the cold reared, possibly due to a lack of stressful conditions. When 10 week old heat reared rats and 11 week old control reared rats were put into the cold chamber, they initially lost weight though they consumed more food than the cold reared rats. After approximately three weeks the heat reared rats began to gain mass at a rate similar to the cold reared rats, while consuming similar amounts of food, indlcating the shorter tall, ears and hind foot of the cold reared rats was of little adaptive advantage, if any with respect to thermoregulation. The control rats had the most difficulty in acclimating themselves to the cold chamber. The inability to acclimate to 
a severe environment may be linked to the nonstressfull conditions under which they were reared.

Though not significantly different than the controls, the cold reared rats had the lowest routine metabolic rate in the cold environment. The controls had the lowest routine metabolic rate in the control and hot environment, followed by the cold reared rats. The heat reared rats did not have the lowest routine metabolic rate in the hot environment possibly because they were acclimated to this temperature and could carry out normal functions.

The kidneys of the control and cold reared rats were significantly heavier, per kilogram of body weight, than the heat reared. The liver of the control reared was significantly heavier, per kilogram of body weight, than the cold reared.

Weekly determined serum thyroid stimulating hormone levels of the control, cold and heat reared rats did not correspond to morphologic measurements. Peaks seen in the cold reared rats corresponded to removal of the mother resulting in a more thorough exposure to the $5^{\circ} \mathrm{C}$ environment. A smaller peak was seen in the heat reared rats also corresponding to the removal of the mother.

Weekly determined serum growth hormone levels of the control, cold and heat reared rats generally did not correspond to morphologic measurements, however at eight weeks of age the comparatively high levels of the heat reared rats did correspond to their larger morphologic measurements. 
1. Ashoub, M. A. 1958. "Effect of Two Extreme Temperatures on Growth and Tail Length in Mice," Nature, 181:284.

2. Barnett, S. A. 1956. "Endothermy and Ectothermy in Mice at -3 C," J. Exp. Bio1., 33:124-133.

3. Barnett, S. A. and B. M. Manly 1956. "Reproduction and Growth of Three Strains of Mice after Transfer to $3 \mathrm{C}, "$. J.'Exp. Biol., $33: 325-329$.

4. Barnett, S. A. and S. G. Scott 1963. "Some Effects of Cold and of Hybridity on the Growth of Mice," J. Exp. Emb. and Exp. Morph., $11: 35-51$.

5. Barnett, S. A. 1965. "Genotype and Environment in Tail Length in Mice," J. Exp. Physiol., 50:417-429.

6. Bass, D. E. and A. Henschel 1956. "Response of Body Fluid Compartments to Heat and Cold," Physiol. Rev., 36:128-144.

7. Bazett, H. C., F. W. Sunderman, J. Droupe and J. C. Scott 1940. "Climactic Effects on the Volume and Composition of B.1ood in Man," Am. J. Physio1., 129:69-83.

8. Baldwin, B. A. and D. L. Ingram 1967. "The Effects of Heating and Cooling the Hypothalamus on Behavioral Thermoregulation in the Pig," J. Physiol., 191:375-392.

9. Becks, H. W., M. E. Asling, M. C. Simpson, C. H. LI and H. M. Evans 1949. "The Growth of Hypophysectomized Female Rats Following Chronic Treatment with Pure Pituitary Growth Hormone," Growth, $13: 175-189$.

10. Becks, H., D. A. Col1ins, M. C. Simpson and H. M. Evans 1949. "The Growth of Hypophysectomized Female Rats Following Chronic Treatment with Pure Growth Hormone; Skeletal Changes, Skull and Dentition," Growth, 13:207-220.

11. Betsel, W. R. , K. A. Woeber, P. J. Bartekonl and S. H. Ingbar 1968. "Growth Hormone Response During Sandfly Fever," J. CIIn. Endo. Met., $28: 1220-1221$.

12. Blfgh, J. 1973. Temperature Regulation in Mamma1s and Other Vertebrates. New York: American Elsevier Inc.

13. Brown-Grant, K. 1956. "Changes in Thyroid Activity of Rats Exposed to the Cold," J. Physiol., 131:52-57. 
14. Campbe11, H. L. 1945. "Seasonal Changes in Food Consumption and Rate of Growth in the Albino Rat," Am. J. Physiol., 143: 428-433.

15. Chan, H. C.,F. C. Chu and M. M. C. Lee 1968. "Effects of Cold on the Skeletal Growth of Albino Rats," Am. J. Anat., 124:239250 .

16. Carlisle, H. J. and D. L. Ingram 1973. "The Influence of Body Core Temperature and Peripheral Temperature on Oxygen Consumption in the Pig," J. Physiol., 231:341-352.

17. Chevillard, L., R. Portet and M. Cadot 1963. "Growth rate of Rats Born and Reared at $5 \mathrm{C}$ and $30 \mathrm{C}, "$ Fed. Proceed., $22: 699-702$.

18. Dean, H. W. and C. P. Lyman 1954. "Body Temperature, Thyroid and Adrenal Gortex of Hamsters During Cold Exposure and Hibernation," Endo., 55:562-569.

19. Del Conte, E. and M. Stux 1954. "Rapidity of Thyroid Response to Cold," Am. J. Physiol., 173:83.

20. Demsey and Astwood 1943. "Determination of the Rate of Thyroid Hormone Secretion at Various Environmental Temperatures," Endo., $32: 509-518$.

21. Emerson, J. D. 1955. "Resistence to Pituitary Growth Hormone," Am. J. Physiol., 181:390-394.

22. Emerson, J. D. and C. M. Emerson 1955. "Fallure of the Rat to Show Continuous Growth in Response to Crude Alkaline Bxtract of Rat Pituitary Giands," Am. J. Physio1., 182:521-523.

23. Evans, H. M., C. W. Asling, M. C. Simpson and H. Becks 1949. "The Growth of Hypophysectomized Female Rats Following Chronic Treatment with Pure Pituitary Growth Hormone; Skeletal Changes, Differences in Response from that of Intact Rats," Growth, 13:191-206.

24. Evans, S. E. and D. L. Ingram 1974. "The Significance of Deep Body Temperature in Regulating the Concentration of Thyroxine in the PIg," J. Physiol., 236:511-521.

25. Evans, S. E. and D. I. Ingram 1977. "Ambient Temperature and the Thyro1d," J. Physio1., 264:159-170.

26. Freinke1, N. and D. Lewis 1957. "The Effect of Lowered Environmental Temperature on the Peripheral Metabolism of Labelled Thyroxine in the Lamb," J. Physiol., 135:288-300.

27. Frewin, D. B., A. G. Frantz and J. A. Downey 1976. "HGH Changes with Temperature and Excercise," Abjebak, 54:97-101. 
28. Galton, V. A. and B. C. Nisula 1969. "Thyroxine Metabolism and Thyroid Function in the Cold Adapted Rat," Endo., 85:79-86.

29. Goss, R. J. 1964. Adaptive Growth. London: Lugos Press.

30. Harrison, G. A. 1958. "Adaptability of Mice to High Environmental Temperatures," J. Exp. Biol., 36:892-901.

31. Harrison G. A. 1959. "Fur Growth of Mice Reared at Different Ambient Temperatures," Äm. Nat., 93:392-397.

32. Harrison, G. A. 1962. "Heterosis and Adaptability in Heat Tolerance of Mice," Gen. 47:427-434.

33. Harrison, G. A. 1963. "Temperature Adaptation as Evidenced by Growth in Mice," Fed. Proceed., 22:691-698.

34. Harrison G. A., R. F. Morton and J. S. Weiner 1958. "The Growth in Weight and Tail Length of Inbred Mice Reared at Two Different Temperatures," Philos. Trans. Royal Soc. Lond., 242: 479-516.

35. Hardy, J. D., A. P. Gagge and J. A. Stalwifk 1970. Physiological and Behavioral Temperature Regulation. Springfeild, Illinois: Char Ies C. Thomas (publisher).

36. Heroux, 0. 1950. Physiology and Pathology of Adaptation Mechantsms. Oxford: Pergamon Press.

37. Heroux 0. and J. St. Piere 1957. "Effects of Cold Acclimatization on Vascularization of Ears, Heart, Liver and Muscels," Am. J. Physto1., 188:163-169.

38. Heroux 0. and N. T. RIdgeman 1958. "The Effect of Cold Acclimation on the Size of Organs and Tissues of the Rat with Specific Reference to Modes of Expression of Results," Can. J. Biochem: Phys101., 36:209-216.

39. Hiller, A. P. 1968. "The B1llary Faecal Excretion of Thyroxine During Cold Exposure in the Rat," J. Phys1o1., 197:123-134.

40. Ingbar, S. H. and P. E. Bass 1957. "The Effect of Prolonged Exposure to Cold on Production and Degradation of Thyroid Hormone in Man," J. Endo., 15:11-111.

41. Ingram, D. I. and K. F. Legge 1972. "The Influence of Deep Body Temperature and Skin Temperature on Respiratory Frequency in the Pig," J. Phys101., 220:283-296.

42. Jansky L. and J. S. Hart 1968. "Cardlac Output and Organ Blood Flow in Warm and Cold Acclimated Rats Exposed to Cold," Can. J. Phys1o1. Pharmaco1., 46:653. 
43. Johansen, K. 1962. "Heat Exchange Through the Muskrat Ta11; Evidence for Vasodilated Nerves to the Skin," ACTA Physiol. Scand., 55:160-169.

44. Kibrick, E. A., H. Becks, W. Marks and H. M. Evans 1941. "The Effects of Different Dose Levels of Growth Hormone on the Tibia of Young Hypophysectomized Female Rats," Growth, 5: $437-447$.

45. Knigge, K. M. 1960. "Neuroendocrine Mechanisms Influencing ACTH and TSH Secretions and Role in Cold Acclimation," Fed. Proc., supp1. $5: 45$.

46. Knigge, K. M. 1960. "Time Study of Acute Cold-induced Acceleration of Thyroidal $\mathrm{I}^{131}$ Release in the Hamster," Proc. Soc. B10. Med., $104: 388$.

47. Knigge, K. M. and S. M. Bierman 1959. "Evidence of CNS Influence Upon Cold Induced Acceleration of Thyroidal I131 Release," Am. J. Physiol., 192:625-630.

48. Knigge, K.M., R. S. Goodman and D. H. Solomon 1957. "Role of the Pitultary, Adrenal and Kidney in Several Thyrold Response of Cold Exposed Hamsters," Am. J. Physiol., 189:415-419.

49. KnIgge, K. M. and D. H. Solomon 1958. "Response of Hamster Thyroid to Cold Exposure and Hemithyroldectomy Compared with Effects of TSH Administration," Fed. Proc., 17:88.

50. Knudson, B. 1962. "Growth and Reproduction of House Mice at Three Different Ambient Temperatures," 01kos, 13:1-14.

51. Leblond, C. P., J. Gross, W. Peacock and R. D. Evans 1944. . "Metbolism of Radiolodine in the Thyroids of Rats Exposed to Increased or Decreased Temperature," Am. J. Physiol., 140: 671-676.

52. Lee, M. M. C., C. P. Chu and C. H. Chan 1969. "Effects of Cold on Skeletal Growth of Albino Rats," Am. J. Anat., 124:239-249.

53. Li, C. H., M. E. Simpson and H. M. Evans 1948. "The Gigantism Produced in Normal Rats by Injection of Pituitary Growth Hormone on Body Growth and Organs," Growth, 12:15-32.

54. L1, C. H., M. E. Simpson and H. M. Evans 1948. "The Gigantism Produced in Normal Rats by Injection of Pituitary Growth Hormone; Tibia, Costochondral Portion and Caudal Vertebrate," Growth, $12: 43-54$.

55. Li, C. H., M. E. Simpson and H. M. Evans 1949. "The Growth of Hypophysectomized Rats Following Chronic Treatment with Pure Pittuitary Growth Hormone; General Growth and Organ Changes," Growth, I3:151-170. 
56. Li, C. H., M.E. Simpson and H. M. Evans 1949. "The Growth of Hypophysectomized Rats Following Chronic Treatment with Pure Pituitary Growth Hormone; Some Chemical Components of the Musculature, Liver and Blood Plasma," Growth, 13: 171-174.

57. Lostoh, A. H. and C. H. Li. 1958. "Effect of Growth Hormone and Thyroxine on Body Weight of Hypophysectomized CH3 Mice," Endo., 62:484-492.

58. Martin C. 1976. Endocrine Physiology. Baltimore: Willams Co.

59. Martin, J. B. 1973. "Neural Regulation of Growth Hormone Secretion," New Eng. J. Med. , 288:1384-1391.

60. Nicholis, D., F. C. Heahy and R. F. Rosisiter 1956. "Phosphorous Metabolism of the Adrenal Gland of the Rat," Can. J. Biochem. Physiol., 34:543-553.

61. Njea, L. R., F. Utne and O. R. Braekkar 1958. "Effects of. Relitive Humidity on Rat Breeding," Nature Lond. 180:1990.

62. Noel, G. L., H. K. Suh, G. Stone and A. G. Franz 1972. "Human Prolactin and Growth Hormone Release during Surgery and Other Conditions of Stress," J. Clin Endo. Met., 35:840-857.

63. Olgle, C. 1934. "Climatic Influence on the Growth of the Male Albino Mouse," Am. J. Physiol., 107:635-640.

64. Okada, Y., K. Miya1, H. Iwatsubo and Y. Kumahara 1970. "HGH Seccretion During Exposure to Hot Air in Normal Adult Male Subjects," J. Clin Endo., 30:759.

65. Okada, Y., K. Matsuoka and Y. Kumahara 1972. "HGH Secretion During Exposure to Hot Air in Normal Adult Male Subjects," J. Clin. Endo. $34: 393-397$.

66. Paolodal, P. R. and E. E. Muller 1968. "Influence of Insuilin Hypoglycemia and Cold Exposure on Release of Pttuitary Growth Hormone in Guinea Pig and Mouse," Gen. Comp. Endo., 10:56-60.

67. Portet, R., L. Chevillard, M. Cabady. and M. Cadot 1963. "Action de la Reserpine sur le Metabolism Respiratoire et la Pres; sion Arterielle des Rats Long-Evans Adaptes a Basse Temperature," Biochem Pharmaco1., 12:154.

68. Ragsdale, A. C. and S. Brody 1922. "The Equivalence of Age in Animals," J. Gen. Physiol., 5:205-214.

69. Rand, R. P., A. C. Burton and T. Ing 1965. "The Tall of the Rat" in Temperature Regulation and Acclimatization," Can. J. Phys. Pharmaco1., 43:257-267. 
70. Rand, C. G., D. S. Riggs and N. B. Talbot 1953. "The Influence of Environmental Temperature on the Metabolism of Thyrold Hormone in the Rat," Endo., 51:562-569.

71. Reading A. J. 1966. "Influence of Room Temperature on Growth of House Mice," J. Mamma1., 47:694.

72. Ring, C. G. 1939. "Thyroid Stimulation by Cold; Including the Effect of Changes in the Body Temperature upon Basal Metabolism," Am. J. Phys1o1., 125:244-250.

73. Robinson S. 1952. "Physiologlcal Effects of Hot and Cold Temperatures," Ann. Rev. Phys101., 14:73-96.

74. Sealander, J. A. 1952. "The Relation of Nest Protection and Huddling to Survival of Mice at low Temperatures," Ecology, $33: 63-71$.

75. Simpson, M. E., A. A. Koneff, H. E. Evans and C. H. LI 1948. "The Gigant1sm Produced in Normal Rats by Infection of P1tultary Growth Hormone; Histological Changes in the Pitultary," Growth, 12:33-37.

76. Simpson, M. E., C. H. L1 and H. M. Evans 1948. "The Gigant1sm Produced In Normal Rats by Injection of P1tuitary Growth Hormone; Main Chemical Components of the Body," Growth, 12:39-42.

77. Simpson, M. E., C. H. L1, H. M. Evans, D. A. Collins, C. W. Asling and H. Becks 1948. "Rat Skull in G1gant1sm," Growth, 12: 55-67.

78. Starr P. and R. Roske1ly 1940. "A Comparison of the Effects of Cold and Thyrold Releasing Factor on the Thyrold Gland," Am. J. Phys101., 130:549-556.

79. Steegmann, A. T. and W. S. Platner 1968. "Experimental Cold ModIfication of Crainiol-faclal Morphology," Am. J. Phys. Anth., $28: 17-29$.

80. Stevans, C. E., S. A. D'Angelo, K. E. Paschls, A. Cantatow and F. W. Sunderman 1955. "The Response of the PItultary System of the Gulnea P18 to Low Environmental Temperature," Endo., $56: 143-155$.

81. StIson, R. H. and K. C. F1sher 1953. "Temperature Selection In Deer Mice," Canad. J. Zoo1., 31:404-416.

82. Straw, J. A. 1969. "Effects of Faecal Welght on Thyro1d Function In Cold Exposed Rats," J. Appl. Phys1o1., 27:630-633.

83. Sumner, F. B. 1909. "Some Effects of External Conditions in the White Mouse," J. Exp. Zoo1., 7:97-155. 
84. Sundstroem, E: S. 1922. "Studies on the Adaptation of Albino Mice to an Artificially Produced Tropical Climate," Am. J. Physiol., 60:397-447.

85. Uotilla, U. U. 1934. "On the Role of the Pituitary Stalk in the Regulation of the Anterior Pituitary with Special Reference to the Thyrotropic Hormone," Endo., 25:605-614.

86. Weaver, M. E. and D. L. Ingram 1969. "Morphologic Changes in Swine Associated with Environmental Temperature," Ecology, $50: 710-713$.

87. Whitton, G. C. 1971 . Comparative Physiology of Thermoregulation. New York: Academic Press. 